\title{
Recovery of Lignocellulosic Waste from Date Palm in Activated Carbon
}

\author{
Bahiani Malika ${ }^{1}$, Kalloum Slimane ${ }^{2}$, Ben ali Lwiza ${ }^{2}$ and Boutadara Khadidja ${ }^{2}$ \\ ${ }^{1}$ Unité de Recherche en Energies Renouvelables en Milieu Saharien, URERMS, Centre de \\ Développement des Energies Renouvelables, CDER, 01000 Adrar, Algeria \\ ${ }^{2}$ University of Ahmed Draia, laboratory of energy, environment and information system Adrar 01000 Algeria \\ E-mail:bahiani.m@hotmail.fr, kalloum_sli@yahho.fr
}

\begin{abstract}
The objective of this study is to evaluate ligno-cellulosic biomass in activated carbons prepared from date palm waste from traditional palm groves of the south-west of Algerian Sahara: petioles, floral handles, fibrillum and spathes, using a simple pyrolysis process $450^{\circ} \mathrm{C}$ preceded by chemical impregnation with $40 \%$ phosphoric acid.

The characterization demonstrates that the mass yields of activated carbon are 51,11 $\pm 3,03 ; 39,98 \pm 3,23$; $46,99 \pm 1,96$ and $43,79 \pm 1,41 \%$ respectively. The iodine index are $247.46 \pm 80.76 ; 786.78 \pm 21.98 ; 596.43 \pm$ 21.98; $494.93 \pm 38.04 \mathrm{mg} / \mathrm{g}$ respectively.

A test for the absorption of activated carbons was evaluated by the nitrate removal test. The nitrates quantities adsorbed by the active carbons are $94.68,95.8,87.84$ and $87.72(\mathrm{mg} / \mathrm{g})$ respectively. The nitrate removal yields were 47.34; 47.9; 43.92 and 43.86\%, respectively. Our results show that activated carbon from petioles and floral stems have the highest amounts of adsorbed nitrate, which are correlated with the highest removal efficiencies.
\end{abstract}

Keywords: biomass, date palm, activated carbon, characterization and adsorption of nitrates.

\section{Introduction}

Today, the growing demand for adsorbent materials to protect the environment is of particular interest particularly in the manufacture of activated carbon from unconventional materials, particularly from plant waste such as food crop residues [1]. The first activated carbons uses were described well before $1550 \mathrm{BC}$ on an Egyptian papyrus and much later around $400 \mathrm{BC}$ by Hippocrates, mainly for medicinal use. In the 18th century, active carbons from blood, wood and bone were used for the liquids purification by filtration or sedimentation [2]. At the beginning of the 19th century the discoloration capacity of charred bones was applied in the sugar refining industry in England [2],[3]. At the beginning of the 20th century, the first processes were developed to produce on an industrial scale activated carbon meeting the requirements of the applications targeted.

Thus, manufacturing methods have improved and the Ostreijko's work [4] has been the starting point for the two basic methods of activated carbon production by physical and chemical activation. Activated carbons global annual production has been estimated at 420000 tones [5] and according to world market forecasts, annual demand growth of $10 \%$ is expected to reach a market of 3 billion dollars in 2017 [6].

In recent years, many studies have focused on the residues valorization from agricultural and agro-industrial sectors in active coals such as rice husks [7], olive [8], cherry [9], dates pits [10], peanut [11], almonds [12],[13] and coconut shells [11], [14] and [15]. In Algeria, the date palm occupies an area estimated at 167,000 hectares for a palm trees number estimated at more than 18.6 million palm trees [16]. Phoenicicultural areas especially the date palm Phoenix dactylifera L., generates significant waste quantities which can constitute a significant agricultural waste source.

Such by-products corresponding to this loss are nevertheless likely to be of considerable economic interest. It is then important to value such ligno-cellulosic biomasses, which are inexpensive and available in large quantities in phoenicicultural areas. In the south-west of the Algerian Sahara, the area reserved for plant-growing 
is 27,804 hectares with more than 3 million date palms [17]. The by-products are available with a very appreciable tonnage justifying their valorization by biotechnological processes adding added value to them. In a context of sustainable development, the present study is a valuation of local lignocellulosic biomass into activated carbon. Our choice was based on four different substrates from the date palm and available in large quantities in traditional palm groves: petioles, floral stems, fibrillum and spathes.

The aim of the present study is to produce activated carbon by chemical activation. Numerous studies report that chemical activation with phosphoric acid results in activated carbons with a better efficiency for the removal of organic and inorganic micro pollutants [18], [19]. We therefore chose chemical activation using phosphoric acid (H3PO4) as a chemical activator. The activated carbons obtained were characterized and their performances were evaluated by the nitrate adsorption test.

\section{Materials and Methods}

\subsection{Vegetable Substrate}

The vegetable substrate represented by the waste of the date palm: the petioles, the floral handles, fibrillum and spathes come from traditional palm groves in the southwest of the Algerian Sahara, 2017's harvest (Fig 1). The biomass used was washed and ground with a micro-grinder and sieved with a $(0.5 \mathrm{~mm})$ sieve. The biomass powders are stored in hermetically sealed glass bottles.

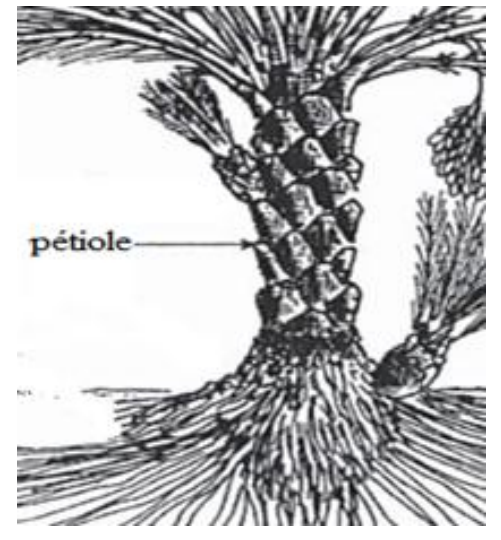

a

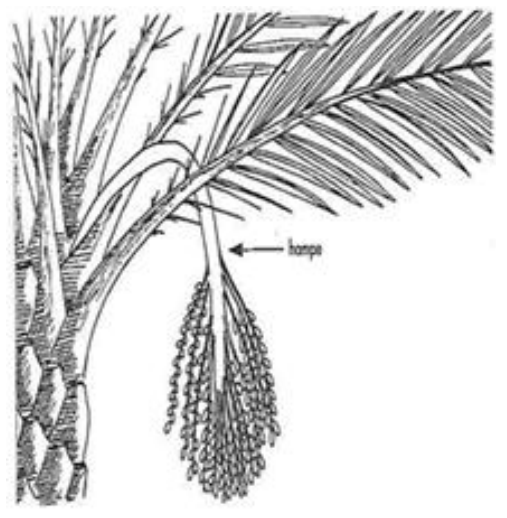

b

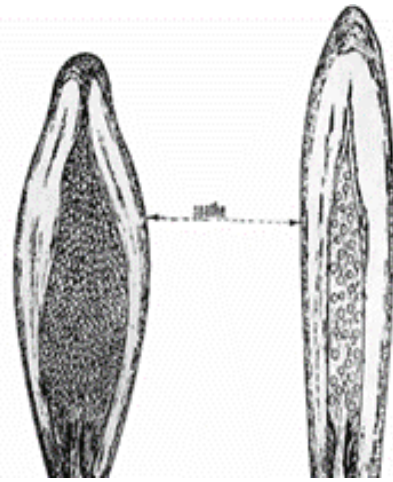

$\mathrm{C}$

Fig.1 different biomasses: petioles (a); Floral handles (b), and spathes (c, [20])

\subsection{Preparation of Activated Carbon}

\subsubsection{Chemical activation with phosphoric acid}

$10 \mathrm{~g}$ of the raw sample, are mixed with $20 \mathrm{~g}$ of the phosphoric acid solution $\mathrm{H}_{3} \mathrm{PO}_{4}$ ( $40 \%$ by mass) and kept under stirring for 8 hours. Afterwards, the samples are placed in an oven for $24 \mathrm{~h}$ at $110^{\circ} \mathrm{C}$.

\subsubsection{Pyrolysis}

The samples are placed in an oven at a temperature of $450{ }^{\circ} \mathrm{C}$ for one hour. The products obtained are washed with distilled water several times until the $\mathrm{pH}$ reaches more than 6.5 . Then dried at $110{ }^{\circ} \mathrm{C}$ for $24 \mathrm{~h} \mathrm{[21]}$.

\subsubsection{Characterization of activated carbon}

\section{Mass yield determination}

Yield is an important quantitative characteristic for active carbons. It reflects the loss of mass of the biomass during its pyrolysis. The expression of the mass yield is given by the following formula [11].

$$
\text { Mass yield }(\%)=\left(\frac{M_{F}}{M_{i}}\right) * 100
$$


Where:

$\mathrm{M}_{\mathrm{f}}$ : weight of the activated carbon obtained

$\mathrm{M}_{\mathrm{i}}$ : weight of the biomass powder (or raw materials).

\section{Determination of iodine index (In)}

The iodine index makes it possible to measure the microporosity of an activated carbon up to $2 \mathrm{~nm}$, the higher its value, the greater the adsorption affinity of the material for small molecules [22]. The iodine index makes it possible to measure the microporosity of an activated carbon up to $2 \mathrm{~nm}$, the higher its value, the greater the adsorption affinity of the material for small molecules [22].

$$
\text { In }=((V b-V s) N(126.9) 0.15) / M
$$

Where:

In : The iodine index in $(\mathrm{mg} / \mathrm{g})$

$(\mathrm{Vb}-\mathrm{Vs})$ : Difference between the titration results in the blank test and the adsorbent test in (ml0.1N of sodium thiosulfate)

N : Normality of the sodium thiosulfate solution in(mol/l).

126.9 : The atomic mass of iodine.

M : Mass of the adsorbent in $(\mathrm{g})$

Elimination of nitrates by adsorption.

The nitrates are reduced to nitrites by a solution of hydrazine in an alkaline medium and in the presence of copper sulphate as catalyst. The nitrites are then assayed by colorimetry: diazotization with sulfanilic acid and capulation with $\alpha$-Naphtylamine.

The nitrate adsorption test was carried out in synthetic solutions of distilled water by adsorption on activated carbon at $0.05 \mathrm{~g}$. A stock solution of nitrates at $100 \mathrm{mg} / \mathrm{l}$ was prepared by dissolving potassium nitrates (KNO3). Different standard solutions of concentrations between 5 and $100 \mathrm{mg} / \mathrm{l}$ of nitrates have been prepared. The optical densities were measured by the UV-visible spectrophotometer at $520 \mathrm{~nm}$. From the calibration curve, residual nitrate levels $(\mathrm{mg} / \mathrm{l})$ were determined [24].

\section{Results and Discussion}

\subsection{Mass yields}

The mass yields of the activated carbon of the substrates: petioles, floral handles, fibrillum and spathes are respectively $51.11 \pm 3.03 ; 39.98 \pm 3.23 ; 46.99 \pm 1.96$ and $43.79 \pm 1.41$ (\%) (Fig. 2).

The highest mass yield of the activated carbon was $51.11 \%$ for the petioles, followed by the fibrillum of $46.99 \%$. while the lowest one was of the floral handles of $39.98 \%$.

With the same activating agent (H3PO4), a mass yield of 59\% was reported on the olive-seed [25], approaching the petiole mass yield of $51.11 \%$ and the yields between 38 - $41 \%$ on sorghum grains [26] approaching mass yields of floral handles and spathes of 39.98 and $43.79 \%$ respectively.

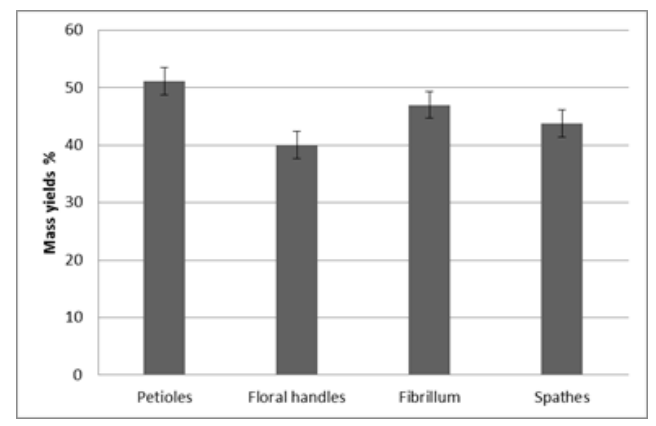

Fig. 2 Mass yields of the various activated carbons 


\subsection{Iodine index}

The iodine index of the activated carbons from the substrates: petioles, floral handles, fibrillum and spathes are respectively $247.46 \pm 80.76 ; 786.78 \pm 21.98 ; 596.43 \pm 21.98 ; 494.93 \pm 38.04 \mathrm{mg} / \mathrm{g}$.

Under the same operating conditions, with the same chemical agent (phosphoric acid) with a concentration of $40 \%$ and a pyrolysis temperature of $450-600^{\circ} \mathrm{C}$, an iodine index of $787 \mathrm{mg} / \mathrm{g}$ was reported on an activated carbon from Shells of coconut [27] which approximates that of the floral handles whose iodine index is 786.78 $\mathrm{mg} / \mathrm{g}$.

The iodine index of activated carbon from fibrillum of the order $596.43 \mathrm{mg} / \mathrm{g}$ is close to that of activated carbon produced from a mixture of rice husks and coffee chaff, of iodine index is $590.55 \mathrm{mg} / \mathrm{g}$ [28]. The spathe iodine index of $494.93 \mathrm{mg} / \mathrm{g}$ was reported in rice husks with an iodine index of $495.30 \mathrm{mg} / \mathrm{g}$ [28]. The iodine index of activated carbon in petioles of the order of $247.46 \mathrm{mg} / \mathrm{g}$ is quite similar to that found in activated carbon from green algae of $305.70 \mathrm{mg} / \mathrm{g}$ (Fig. 3), [29].

There is therefore a proven correlation between the iodine value and the specific surface area. It has been established that the iodine index gives an estimate of the specific surface area [10], indicating the adsorption capacity in the micropores [30]. The activated carbon from the floral stem shows the highest iodine index of $786.78 \mathrm{mg} / \mathrm{g}$ which would reflect a very high adsorption capacity.

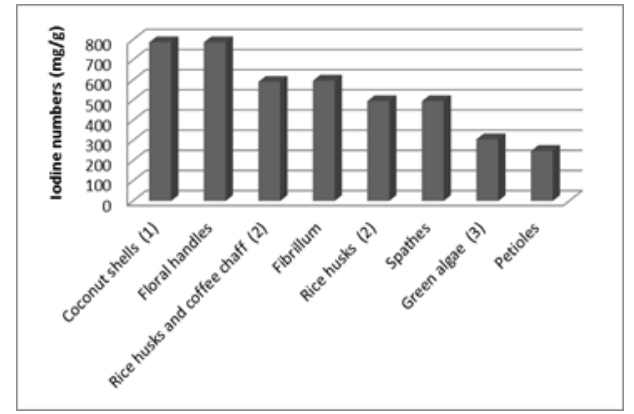

Fig. 3 Index of iodine of the active carbons of the various substrates compared with those resulting from different biomasses and under the same operating conditions. (1: [27], 2: [28], 3: [29])

\subsection{Adsorbed nitrates quantities}

The adsorbed nitrates quantities by the active carbons from petioles, floral handles, fibrillum and spathes are respectively 94.68; 95.8; 87.84 and 87.72 (mg/g) (Fig. 4).

The absorbed nitrates highest amount was that of activated carbon from the floral handles of $95.8 \mathrm{mg} / \mathrm{g}$ followed by that of activated carbon from petioles of the order of $94.68 \mathrm{mg} / \mathrm{g}$.

Under the same operating conditions, studies [31] and [32] reported adsorbed nitrates quantities with adsorbent materials: functionalized chitosan beads and chitosan hydrogel beads of the order of $90 \mathrm{mg} / \mathrm{g}$ and 92.1 $\mathrm{mg} / \mathrm{g}$ respectively, which approximates the amounts adsorbed by the active carbon of the floral handles and petioles of the order of $95.8 \mathrm{mg} / \mathrm{g}$ and $94.68 \mathrm{mg} / \mathrm{g}$.

On the other hand, the adsorbed nitrates quantities by the active carbons of fibrillum and spathes of 87.84 and $87.72(\mathrm{mg} / \mathrm{g})$, respectively, approach that reported on another chitosan adsorbent material: $\mathrm{Fe}_{3} \mathrm{O}_{4} / \mathrm{ZrO}_{2} /$ chitosan, of the order of $89.3 \mathrm{mg} / \mathrm{g}$ [31]. 


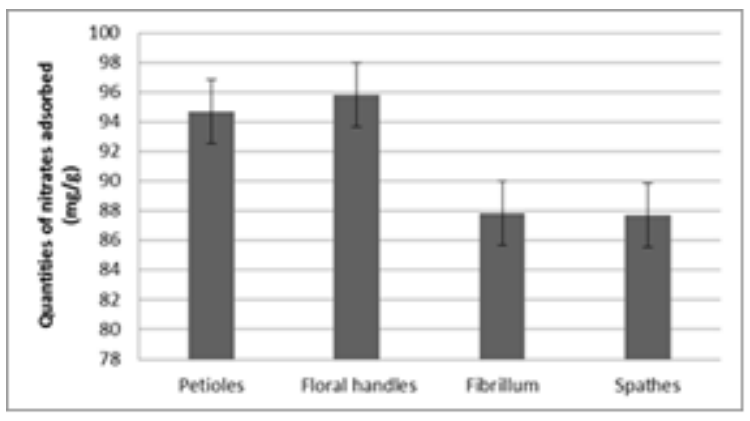

Fig. 4 Quantities of nitrates absorbed from the various activated carbons

\subsection{The nitrate removal yields}

The nitrate removal yields by the active carbons from petioles, floral handles, fibrillum and spathes are respectively $47.34 ; 47.9 ; 43.92$ and 43.86 (\%) (Fig.5).

The highest nitrate removal efficiency was obtained in the floral handles of $47.90 \%$, which corresponds to the lowest residual content of $52.1 \mathrm{mg} / \mathrm{l}$. The lowest nitrate removal yield was obtained in the spathes of $43.86 \%$, which corresponds to the highest residual content in the order of $56.14 \mathrm{mg} / \mathrm{l}$. The highest removal yield of $47.9 \%$, corresponding to an initial nitrates concentration of $100 \mathrm{mg} / \mathrm{l}$.

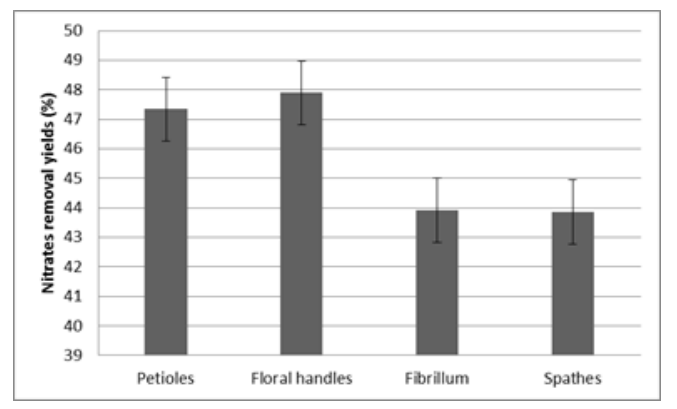

Fig.5 Nitrate removal yields of different activated carbons

\section{Conclusion}

Our study shows that the iodine index of the active carbons of the four biomasses are between 247.46$786.78 \mathrm{mg} / \mathrm{g}$. The iodine, active carbons of the floral handles and fibrillum indexes of 786, 78 and $596.43(\mathrm{mg} / \mathrm{g})$ respectively are the highest, indicating an attractive absorptive capacity.

However, the nitrate adsorption test revealed that the best removal yields were $47.9 \%$ and $47.34 \%$, respectively, of active carbons from floral handles and petioles. This correlates with the adsorbed nitrate quantities, the highest of which are active carbons from floral handles and petioles with amounts of the order of $95.8 \mathrm{mg} / \mathrm{g}$ and $94.68 \mathrm{mg} / \mathrm{g}$ respectively. This could be explained by the fact that the active carbon from the floral handles and the petioles are in the form of powder, unlike the activated carbon derived from the fribrillum. Studies report that powdered activated carbon is characterized by a specific surface area greater than the specific surface area of the activated carbon. This may explain why activated carbon powder is a better adsorbent. Thus, the use of these activated carbons, derived from ligno-cellulosic biomasses, as low as adsorbent could be a promising prospect in the treatment of industrial wastewater.

\section{References}

[1] A.A.M. Daifullah, B.S. Girgis, H.M.H. Gad, Colloids and surfaces A: physicochemical an engineering aspects, Vol. 235, 2004, pp. 1-170. 
[2] N. Kania, Utilisations de charbons actifs dans des procédés d'adsorption de Composés Organiques volatils et des procédés de catalyse dans l'eau, Thèse Doctorat en chimie organique et macromoléculaire, Université d'Artois, 2010, $153 \mathrm{p}$.

[3] N. Sedira, Etude de l'adsorption des métaux lourds sur un charbon actif issu de noyaux de dattes, Mémoire de Magister en chimie physique et analytique, Université de Souk Ahras, Algérie, 2013, 118p.

[4] R. Von. Ostreijko, Patents, 1900 and 1902.

[5] L. Meljac, Etude d'un procédé d'imprégnation de fibres de carbone activées Modélisation des interactions entre ces fibres et le sulfure d'hydrogène, Thèse de doctorat, Université Saint Etienne, France, 2004, 240p.

[6] Global Activated Carbon Market Forecast and Opportunities, 2017.

[7] J.N Sahu, S. Agarwal, B.C Meikap and M.N Biswas, Performance of a modified multi-stage bubble column reactor for lead (II) and biological oxygen demand removal from wastewater using activated rice husk, J. Hazard. Mater, Vol.161, 2009, pp. 317-324.

[8] A. Rodriguez, R. Lama, A. Rodriguez, Jimenez, R.L. Guillen and J. Fermandez-Bolonos, Olive stone an attractive source of bioactive and valuable compounds, Bioresource Technology, Vol.99, 2008, pp. 5261-5269.

[9] J. Jaramillo, V. Gómez-Serrano and P.M. Alvarez, Enhanced adsorption of metal ions onto functionalized granular activated carbons prepared from cherry stones, J.Hazard. Mater, Vol.161, 2009, pp. 670-676.

[10]B.S. Girgis and A.N.A. El-Hendawy, Porosity development in activated carbons obtained from date pits under chemical activation with phosphoric acid, Microporous and Mesoporous Materials, Vol.52, N2, 2002, pp.105-117.

[11]M. Gueye, Développement de charbon actif à partir de biomasses lignocellulosiques pour des applications dans le traitement de l'eau, Thèse de Doctorat, Institut International de l'Ingénierie de l'Eau et de l'Environnement (2iE), 2015, 229p.

[12] A. Martínez de Yuso, B. Rubio, M.Teresa Izquierdo, Influence of activation atmosphere used in the chemical activation of almond shell on the characteristics and adsorption performance of activated carbons, FuelProcessing Technology, Vol.119,2014, pp. 74-80.

[13]E. Demirbas, M. Kobya, A.E.S. Konukman, Error analysis of equilibrium studies for the almond shell activated carbon adsorption of Cr (VI) from aqueous solutions. J. Hazard. Mater., Vol. 154, 2008, pp. 787-794.

[14]Z. Hu, and M.P. Srinivasan, Preparation of high-surface-area activated carbons from coconut shell. Microporous and Mesoporous Materials, Vol. 27, $\mathrm{N}^{\circ} 1,1999$, pp. 11-18.

[15] S. Babel and T.A. Kurniawan, Cr (VI) removal from synthetic wastewater using coconut shell carbon and commercial activated carbon modified with oxidizing agents and/or chitosan. Chemosphere, Vol., 54, Nº7, 2004, pp. 951-967.

[16] Statistiques, 2015. Ministère de l'Agriculture et du Développement Rural, Algérie.

[17] Statistiques, 2015. Direction des services agricoles d'Adrar, Algérie.

[18] O. Ioannidou and A. Zabaniotou, Agricultural residues as precursors for activated carbon production, A review. Renewable and Sustainable Energy Reviews.,Vol. 11, №9, 2007, pp.1966-2005.

[19] M.J. Prauchner and F. Rodriguez-Reinoso,Preparation of granular activated carbons for adsorption of natural gas, Microporous Mesoporous Mater., Vol. 109, 2008, pp.581-584.

[20] P. Munier, Le palmier dattier, Maison neuve et larose, Paris, 1973, 367p.

[21] Y. Sun, Q. Yue, B. Gao, L. Huang. X. Xu and Q. Li, Comparative study on characterization and adsorption properties of activated carbons with $\mathrm{H}_{3} \mathrm{PO}_{4}$ and $\mathrm{H}_{4} \mathrm{P}_{2} \mathrm{O}_{7}$ activation employing Cyperus alternifolius as precursor. Chem. Eng. J., Vol. 181-182, 2012, pp. 790-797.

[22] I. Tchakala , L. Moctar Bawa, G. Djaneye Boundjou , K. S. Doni et P. Nambo, Optimisation du procédé de préparation des charbons actifs par voie chimique $\left(\mathrm{H}_{3} \mathrm{PO}_{4}\right)$ à partir des tourteaux de karité et des tourteaux de coton, International Journal Biological and Chemical Science, 2012, 461-478pp. 
[23]M. J. Ahmed and S. K. Dhedan, Equilibrium isotherms and kinetic modeling of methylene blue adsorption on agricultural wastes-based activated carbons, Fluid Phase Equilibria, Vol. 317, 2012, pp.9-14.

[24] J. Rodier, B. Legube, N. Merlet, L'analyse de l'eau, Ed. Dunod, 2009, pp. 78-1368.

[25] G. Stavropoulosand A. Zabaniotou A, Production and characterization of activated carbons from olive-seed waste residue, Microporous Mesoporous Mater., Vol.82, 2005, pp. 79-85.

[26] Yulu Diao W.P. Walawender and L.T. Fan, Activated carbons prepared from phosphoric acid of grain sorghum, Bioresource Technology 2000, Vol.81, 2002, pp.45-52.

[27]C. K. Balogoun, L. M. Bawa, S. Osseni et M. Aina, Préparation des charbons actifs par voie chimique à l'acide phosphorique à base de coque de noix de coco, Int. J. Biol. Chem. Sci. Vol.9, No1, 2015, pp. 563-580.

[28]D. R .TchuifonTchuifon, Adsorption des composés phénoliques sur des charbons actifs préparés par activation chimique des balles de riz et des marcs de café, Thèse de doctorat. Université de dschang Cameroun, 2016, 152p.

[29]F. Nemchi, Modification physique-chimique de deux algues marines ulva lactuca et cystoseira stricta en vue de l'élimination par adsorption du bleu de méthylène, Mémoire de Magister, Université d'Oran Algérie, 2006, 99p.

[30] A. W Verla, M. Horsfall (Jnr), E.N. Verla, A. I. Spiff and O.A. Ekpete, Preparation and characterization of activated carbon from fluted pumpkin (Telfairia occidentalis Hook. F) seed shell, Asian Journal of Natural \& Applied Sciences, Vol. 1, N³, 2012, pp. 39-50.

[31] A. Rajeswari, A. Amalraj, A. Pius, Adsorption studies for the removal of nitrate using chitosan/PEG and chitosan/PVA polymer composites, Journal of Water Process Engineering, Vol.9, 2016, pp. 624-302.

[32] A. Dioum, Elimination des nitrates en solution aqueuse par adsorption sur un organo silcate mésoporeux de type SBA15, Mémoire, Université Laval Québec, 2013, 109p. 